
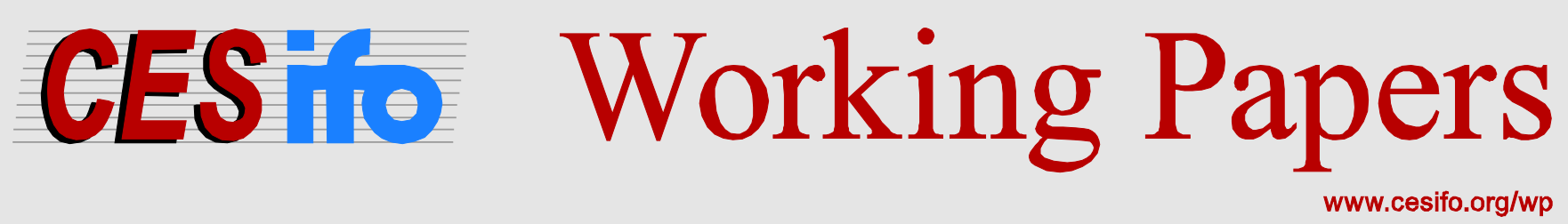

\title{
Revenue for EMU: \\ A Contribution to the Debate on Fiscal Union
}

\author{
Anna Iara \\ CESIFO WORKING PAPER NO. 5794 \\ CATEGORY 1: PUBliC FinANCE \\ MARCH 2016 \\ An electronic version of the paper may be downloaded \\ - from the SSRN website: Www.SSRN.com \\ - from the RePEc website: Www.RePEc.org \\ - from the CESifo website: www.CESifo-group.org/wp
}




\title{
Revenue for EMU: A Contribution to the Debate on Fiscal Union
}

\begin{abstract}
In the wake of the euro area crisis, the debate on instruments to deepen economic integration among its members has intensified, among others putting forward a fiscal stabilization capacity for EMU members. Contributions made so far to further this idea have mostly concentrated on the expenditure side and possible stabilisation properties. This analysis reviews the most important proposals and discusses design choices and institutional conditions to develop the revenue side of such a fiscal instrument.
\end{abstract}

JEL-Codes: H290, H770, H870.

Keywords: European Union, EMU, fiscal federalism, fiscal integration, EU budget.

\author{
Anna Iara \\ European Commission \\ Secretariat-General \\ Brussels / Belgium \\ anna.iara@ec.europa.eu
}

Most of this paper was written while the author was staff member of the European Commission's Directorate-General for Taxation and Customs Union. The views expressed in this paper are the authors' alone and do not necessarily correspond to those of the European Commission and its Services. Comments by Roel Beetsma, Thomas Hemmelgarn, Shafik Hebous, Philip Kermode, Gaëtan Nicodème, Baudouin Regout, Sandor Richter, and an anonymous referee are gratefully acknowledged; errors and omissions are those of the author only. 
The economic and financial crisis has set a process of deepened European economic policy integration in motion. The recent economic governance innovations at the EU level aimed at improving fiscal discipline, economic policy co-ordination and crisis resolution - the six-pack and two-pack legislations, the European Stability Mechanism and financial support to insolvent sovereigns, and the Fiscal Compact, to name the most important - were considered inconceivable before the crisis. Conclusions from US history and extrapolation of recent EU experience fuel expectations that EMU might be deepened in the not too distant future. European leaders have picked up these expectations to formulate a framework for the way forward. The topic has also been addressed by think tanks and academia since, and policy debate on the topic is evolving.

This analysis summarizes the policy debate on fiscal union, in particular focusing on proposals for a euro area instrument for stabilisation of asymmetric shocks, and adds considerations concerning the revenue side. Two dimensions are essential about a central fiscal policy framework to be labelled fiscal union: (i) the mechanism for pooling resources to provide for expenditure, and (ii) the governance of this mechanism. ${ }^{1}$ Common fiscal governance rules or some co-ordination of budgetary policy making, as practiced under the strengthened Stability and Growth Pact in the EU, are governed by a supranational fiscal policy framework but fall short of fiscal union. The European policy debate so far has focused on four functions of such common resource pooling: (1) fiscal stabilisation linked to macroeconomic aggregates, (2) a micro approach of unemployment insurance, (3) joint resources for a fiscal backstop in systemic financial crises, and (4) the lender of last resort function for illiquid sovereigns more broadly. Our discussion relates to the first two of these but disregards the others, given that policy instruments are being designed on these under the banking union agenda and the European Central Bank's OMT programme respectively.

A common fiscal stabilisation instrument for the euro area would be a major step of economic policy integration. At the culmination of the euro area debt crisis, calls for an EMU wide instrument to provide insurance against asymmetric shocks to members of the euro area were widespread, backed by the argument that a currency argument is incomplete without such a tool. In the debate, the United States have served as a natural reference: indeed, the synchronicity of business cycles has reached levels comparable to US regions in the euro area (Ferreira-Lopes and Pina, 2011). In the US, fiscal stabilisation provided at the federal level is found to have provided for the smoothing of about 13 per cent of the shocks to state-level income (Asdrubali et al., 1996), whereas the euro area does not have such a tool at her disposal so far. ${ }^{2}$ True, national debt policy could also be used to a higher extent to provide for the smoothing of income shocks by fiscal means. Within the limits imposed by the common fiscal framework of the European Monetary Union and notably in the presence of incomplete capital market integration this might not be sufficient though (Sorensen and Yosha, 1998), while rainy day funds to allow go beyond these limits in the case of a severe shock are unlikely to be set up in uniquely national frameworks for political economy reasons. Furthermore, to recreate significant fiscal

1 For a consistent discussion of various notions of what concepts of fiscal union in the EMU context might include, see Fuest and Peichl (2012).

${ }^{2}$ At the same time, as increasingly emphasised in the ongoing debate, in the US capital markets play a pivotal role for cushioning regional economies from the impacts of macroeconomic shocks, providing stabilisation of about $40 \%$ (ibid.); such shock absorbers are also severely underdeveloped in the euro area. 
capacity to be ready to counter asymmetric shocks with fiscal means, each member state would have to severely reduce their levels of public debt, which is a long-term project indeed. Thus while an overall EU level fund might operate similar to separate national rainy day accounts, it would have the additional advantage of cheap access to funding in the case of extraordinary shocks that might exhaust such funds and prohibit the access to capital at acceptable interest rates, and thus usefully complement the available crisis instruments at the EU level. Furthermore, a common fiscal insurance fund could build on the enforcement power of a commonly agreed and operated mechanism outside the full control of national policy-makers, thus ultimately fostering a higher degree of anticyclical conduct to national fiscal policy as presently the case and prescribed by the Stability and Growth Pact. For these reasons, a carefully designed common fiscal instrument to cushion asymmetric shocks has the potential to give new meaning to horizontal equity and "fair return" among participating countries. The idea of an EMU stabilisation fund also raises scepticism however, mostly due to the risk of moral hazard inherent to any insurance scheme: reliance on payments from the fund might depress participating countries' willingness to undertake painful structural reform to improve resilience: therefore, mechanisms to suppress moral hazard - mainly concerning the expenditure side - will be crucial in the set-up and for the political acceptability of the common instrument.

The present paper is aimed at contributing to the reflection concerning the revenue side of a common stabilisation instrument for EMU. So far, only few contributions have addressed this facet of the debate. Our discussion provides consideration to aspects with specific relevance for the development of the EU institutional framework. These aspects include the commitment to the Community method, the key objective to foster the value added of EU policies, the opportunity to address legitimacy concerns, and the momentum to bring dynamism into the debate own resources. As a point of departure, this means in particular that GNI-type contributions would be the easiest but not the best choice as they perpetuate the logic of fair return without building a sense for the common good. Also specificities governing the EU budget do not appear to be an obstacle to build an EMU stabilisation fund under the Community method, if there is the willingness to do so.

This analysis is structured as follows. Section 2 sets the scene by briefly reviewing the most important contributions to today's fiscal union debate that have mostly focused on the expenditure side. Section 3 discusses different criteria for consideration when designing the revenue side of fiscal union. Section 4 studies the possibility to integrate a fiscal stabilisation capacity in to the EU budget. Section 5 concludes. A recollection of key characteristics of possible basses for EMU revenue is provided table format in the Annex.

\section{Fiscal union in EMU: The debate to date}

\subsection{A summary of official proposals}

In the second half of 2012, European leaders took several steps to draw a roadmap for the completion of EMU. At the European Council meeting of 26-27 June 2012, European Council President Herman van Rompuy sketched out a report "Towards a genuine Economic and Monetary Union". It specifies the building blocks of (i) an integrated financial framework, (ii) fiscal integration, (iii) a strong framework for economic policy coordination, and (iv), democratic legitimacy and accountability. As a follow-up of this guidance, the European Commission (2012) launched its Blueprint for a deep and 
genuine EMU on 28 November 2012, where the steps towards deeper EMU are scheduled in three phases. The short-term agenda (within 18 months) encompasses the implementation of the new European economic and fiscal governance framework laid down in the six-pack and two-pack legislations, the adoption of proposals on joint banking supervision and resolution, the design of a financial instrument to foster economic reform in the Member States, and the assumption of joint external representation of the euro area. In the medium term (up to five years), it is foreseen to deepen economic and budgetary policy integration, including the creation of a fiscal capacity for the euro area, a debt redemption fund, and the common issuance of short-term sovereign debt (eurobills). In the long term (beyond five years), the Blueprint foresees the completion of the bank supervision and resolution scheme and the building of a common deposit guarantee insurance scheme, as well as the implementation of a euro area fiscal capacity for stabilisation against asymmetric shocks. The fiscal integration process would also lead to the common issuance of public debt with longer maturities. The Union has already progressed in achieving the first items of this ambitious agenda. Notably, the sixpack and two-pack legislations have been firmly entrenched into European economic governance, and agreement on the framework for banking resolution is being finalised, while the European Central Bank has been assigned centralised supervisory powers. Exploring possibilities to design a system of "mutually agreed contractual arrangements and associated solidarity mechanisms" in view of reaching agreement is tabled for the European Council in October 2014. ${ }^{3}$

Building on the Commission Blueprint, the approach of the European Council President has been more fully developed in a report of 5 December 2012 (van Rompuy et al., 2012). The report of the European Council President in co-operation with the Commission, ECB, and Eurogroup Presidents breaks down the completion of EMU along the above four dimensions in concrete steps within specified time frames. It suggests the creation of a "well-defined and limited" fiscal capacity to provide insurance at the central level against shocks, once that a common regulatory and supervisory financial framework and stronger coordination of structural reforms have been established, foreseen to happen after 2014. Besides, it proposes to complement the adoption of a fiscal capacity by increasing degrees of joint budgetary decision-making and policy coordination notably concerning taxation and employment. The report also presents some criteria for the capacity: it should (i) not lead to permanent unidirectional transfers or income equalisation, (ii) not add to moral hazard in relation to fiscal discipline and structural reform, (iii) not to serve as a crisis instrument, and (iv) be consistent with subsidiarity and not increase levels of public revenue and expenditure.

Most recently, the road toward fiscal integration in EMU has been further developed by the report of the president of the European Commission in cooperation with the heads of the European Council, European Parliament, European Central Bank, and the Eurogroup (Juncker et al., 2015). This so-called "Five Presidents' report" distinguishes two stages of the road toward completing EMU. The first stage is confined to making full use of, and ensuring full compliance with, the existing framework of common economic policy making that has been considerably further developed in the recent years. As concerns fiscal integration, in the second stage - set to begin with the second half of 2017 - it is proposed to make a process of convergence towards similarly resilient economies more binding. The

\footnotetext{
${ }^{3}$ See the conclusions of the European Council of 19/20 December 2013.
} 
report proposes to establish some common standards in the area of labour markets, competitiveness, business environment, public administrations, and some aspects of tax policy, and proposes convergence toward more resilient economic structures in those areas as a condition for access to a common shock absorption mechanism.

\subsection{Other contributions on fiscal union in EMU}

\subsubsection{A chronology of leading contributions}

Contributions to the search of the way forward provided by other official organisations, academia, and policy think-tanks show a variety of approaches to fiscal union. In chronological order, the policy debate built up with the following milestone contributions that also give a flavour of orders of magnitude. Among the first comprehensive proposals for deepening EMU, the "Tommaso PadoaSchioppa group" of economic thinkers and leaders (Enderlein et al., 2012) has suggested a "sui generis" approach for fiscal federalism in EMU. Launched on the eve of the June 2012 European Council summit, the report calls for a cyclical insurance fund under the strict control of national parliaments, to provide for automatic macroeconomic stabilisation without long-term redistribution. Besides it advocate expanding the redistributive side of the EU budget by means of increasing the EU's own resources and calls for a common regulatory, supervisory, and deposit insurance framework for banking. Thirdly it calls for the creation of a European Debt Agency to issue jointly and severally guaranteed debt by all euro area members, to establish a liquid market for part of sovereign funding at normal levels, as well as to allow access to sovereign financing in the build-up of a self-fulfilling solvency crisis, with a parallel reduction of political sovereignty. Next, as a lead representative of the 'micro approach' to stabilisation, Dullien (2012, updated: ibid., 2013) has suggested the creation of short-term unemployment insurance at the European level. Such funding would directly go to citizens and be spent for consumption in case of a downturn. The analysis elaborates that the design of an EMU wide unemployment insurance scheme is possible without causing large permanent transfers across countries and highlights the contribution of such schemes to national stabilisation policies. Dullien advocates employees' contributions to fund compensation for a certain level of earnings shortfalls, e.g. 50 per cent, in case of unemployment up to one year; the common scheme would be complemented in duration and compensation levels by national schemes. He estimates revenue needs and pay-outs of such a fund of about $0.7 \%$ of euro area GDP, necessitating payroll tax contributions of $1.7 \%$ to balance the system over time. Again on the macro side of approaches, on behalf of the Brussels-based think tank Bruegel, Wolff (2012) has called for a euro area fiscal capacity of up to 2 per cent of euro area GDP. According to this proposal, transfers would be linked to large output gaps for stabilisation of asymmetric shocks at the level of national budgets. ${ }^{4}$ Additionally, a borrowing capacity would allow address area-wide recessions and serve as a fiscal backstop for banking crises.

On behalf of the International Monetary Fund a staff discussion note (Allard et al., 2013) has identified four essential "minimal elements for a fiscal union" in order to enhance the resilience of the

\footnotetext{
${ }^{4}$ Wolff (ibid.) additionally suggests the adoption of a borrowing capacity to allow address area-wide shocks and to serve as a fiscal backstop for banking crises. The core of the debate on a fiscal capacity for the euro area however is about an instrument to support participating countries' stabilisation efforts in the advent of asymmetric shocks.
} 
monetary union against future crises: first, better oversight and incentives conducive to prudent fiscal policy making at the national level are called for, basically requiring a thorough and systematic application of the European fiscal governance reforms taken in the course of the crisis. Next, some degree of centralised fiscal risk-sharing and public goods provision is advocated conditional on a framework providing better oversight and incentives. It is left open if this should take the form of a joint rainy day fund, unemployment insurance, or a genuine euro area budget with revenue- and expenditure-side stabilisation, while pros and cons of these options are carefully discussed. Besides, an area-wide fiscal backstop for the banking sector is considered necessary, that should be financed by sector levies but supported by a credit line from the ECB and/or pooled fiscal resources in case of systemic crisis. Finally, common debt issuance backed by common revenue, to finance risk sharing and fiscal backstops and to provide a safe asset, is considered as a long-term solution.

The European Commission's Directorate-General for Employment and Social Affairs has looked into different options to provide for euro area stabilisers liked to unemployment. A report of its staff (Bontout and Lejeune, 2013) considers three options: (1) non-earmarked transfers to Member States triggered by high unemployment, (2) transfers to Member States triggered by high unemployment that would be earmarked for unemployment benefit expenditure, conditional upon minimum labour market policy standards, and (3) a EMU-wide unemployment benefit system with common financing and common provisions, to be topped up by Member States. The report makes the case for linking transfers to the national unemployment rate (instead of other measures such as the output gap) and earmarking these for unemployment benefit support, in effect arguing for a genuine supplementary EMU unemployment scheme. The analysis provides evidence of the complexity of the task to provide common ground to unemployment schemes at the EMU level, given high institutional heterogeneity at the level of Member States.

A staff paper of the French Ministry of Finance (Caudal et all, 2013) discusses the options to adopt a euro area budget with the objective to maximise stabilisation properties. It suggests create a genuine euro area budget for stabilisation purposes, selecting the most cyclically responsive revenue and expenditure items, in particular corporate tax revenues and unemployment insurance, for that purpose.

In autumn 2013, a German and a French group of leading economists respectively have put forward their concept of deepening EMU. The 'Glienicker Group' of German policy analysts, economists, and lawyers (von Bogdandy et al., 2013) backs the proposition of a EMU short-term unemployment insurance fund, it also advocates an EMU fund of 0.5\% of GDP collected form Member State contributions to finance growth-enhancing investment in countries undergoing budgetary consolidation and structural reform, besides it calls for turning the ESM into a fully-fledged European Monetary Fund to credibly counter self-fulfilling liquidity crisis threatening EMU Members, and finally it urges the rapid implementation of banking union including common banking regulation, supervision, and resolution. The vision of an "euro area community" of the 'Eiffel Group' of French intellectuals, to be equipped with an independent budget and own resources (Bénassy-Quéré et al., 2014a), looks as follows: the focus is not on improving the resilience of the euro area vis-à-vis macrofinancial crises but on providing answers to threats to social and ecological sustainability that are tangible to citizens. The proposal foresees an own euro area budget to provide for stabilisation via common unemployment insurance, and for the provision of public goods such as workers' training, fostering labour mobility, and financing energy, industry, and service infrastructures. The financing of own resources, finally, is proposed from receipts of corporate or environmental taxation. Besides, a certain degree of tax base harmonisation and the setting of ranges for tax rates is proposed. 
Another contribution from France was made more recently by the French Council of Economic Advisers (Bénassy-Quéré et al., 2014b), that is the first to focus on the revenue side of a euro area budget. The authors recommend moving forward with the common consolidated corporate tax base (CCCTB) project at the EU level, possibly under enhanced cooperation; the financial sector is seen a particularly useful nucleus of a common approach to broader corporate income taxation. The receipts of a EU level tax on financial activity are proposed to feed the common bank resolution fund and a euro area budget for stabilisation purposes.

On the academic side, Dolls et al. (2016) have embedded the idea of a fiscal stabilisation fund into a broader approach to render the institutional architecture of EMU resilient also to large financial shocks. Their key point is to combine fiscal insurance with an explicit procedure to restructure the debt of insolvent euro area members as two complementary elements of a broader approach to stability in EMU. On the former, the preferred option of the authors is an EMU-wide unemployment insurance system to be accessible for co-financed short-term unemployment benefits upon specific trigger levels of unemployment. The respective financing needs are established with reference to Dolls et al. (2015). To minimise moral hazard with respect to the scheme, the authors propose the compulsory adoption and sustainment of the proposed sovereign insolvency procedure as well as compliance with the guidance given under the Stability and Growth Pact and European Semester framework respectively.

Not all members of the international research and policy community have been eager to embrace the concept of a risk-sharing fiscal instrument for the euro area. Exploring concepts and reviewing possible arrangements discussed under the notion of "fiscal union for EMU", Fuest and Peichl (2012) underscore the need for significant political integration beyond the current state of affairs for a EMU fiscal union to function, and advocate the restoration of decentralised responsibility of government debt and financial sector reform instead. Likewise, in their annual economic review of the euro area, the OECD (2014) puts emphasis on the risks rather than the benefits of a common fiscal instrument, highlighting a high level of cross-country business cycle correlation in the euro area and alerting about the challenges of the proposed mechanisms for cyclical risk sharing.

The above contributions to the debate are discussing broad aspects of possible approaches to a fiscal stabilisation capacity based on simple calculations. Specific mechanisms, notably inter-budgetary schemes and unemployment benefit schemes for the euro area have also been studied in more technical detail: these findings can provide a more accurate impression about the operation of an EMU stabilisation fund and the associated challenges. Carnot et al. (2015) investigate different designs of an inter-budgetary transfer mechanism, including options to address idiosyncratic shocks only, and designs to cover area-wide shocks as well. They consider various combinations of payments into and out of the fund, with and without threshold conditions, of about $25 \%$ of country-specific output gaps, in absolute terms or relative to the area-wide average. For these conditions, they estimate that the fund would require payments by participating countries of no more than $0.8 \%$ of national or $0.08 \%$ of area-wide GDP. The schemes would be able to reduce the variance of national output gaps relative to the euro area by at least $10 \%$ in the participating economies. Simulations with ex-post data over 20032012 show that the different output gap-based schemes considered would have remained close to balance over the studied period, although substantial differences are found between flows based on expost and real-time data respectively. Dolls et al. (2015) provide a scrutiny of key design aspects of a common unemployment insurance mechanism to the euro area based on simulations with micro data. They calculate that with annual payments of about 47 bn euro, less than 0.5 per cent of the combined GDP of the countries considered, in 2009 - the year with the highest increase in unemployment - an 
unconditional scheme with a replacement rate of 50\% any for new unemployment up to 12 months could have provided on average a gain in stabilisation in addition to the status quo of 12 and 6 per cent of the gross income shock for household incomes and public budgets respectively on average. Their findings also show that such a fund would have given rise to permanent net flows, for five of the 18 countries in this specific case.

\subsubsection{An EMU fiscal capacity: features of design}

The debate has brought some characteristics and criteria considered central to emerging fiscal union to the fore. Key to the debate is the idea to equip the euro area specifically - and not the EU as a whole with a common budget. The budget is seen to serve the purpose of stabilisation in Member States hit hard by asymmetric shocks, with variants also foreseeing a common facility - including the ability to contract debt at the euro area level - for area wide stabilisation. There is agreement that such a new budget must not result in permanent transfers, and that moral hazard weakening incentives to maintain national budgetary stability and momentum for structural reform must be contained.

The above proposals on fiscal union suggest various combinations of revenue and expenditure. The pairings are schematically illustrated in the table below.

\begin{tabular}{|l|l|l|l|}
\hline & Revenue & Expenditure & Proposals \\
\hline (A) & $\begin{array}{l}\text { Gross national income } \\
\text { (GNI)-type payments out of } \\
\text { national budgets }\end{array}$ & $\begin{array}{l}\text { Grants to national budgets, } \\
\text { non-earmarked }\end{array}$ & $\begin{array}{l}\text { Wolff, 2012; Enderlein et al., } \\
2013 \text {; Bontout and Lejeune, } \\
2013\end{array}$ \\
\cline { 3 - 4 } & & $\begin{array}{l}\text { Grants to national budgets, } \\
\text { earmarked for MS UB }\end{array}$ & Bontout and Lejeune, 2013 \\
\cline { 3 - 4 } (C) & $\begin{array}{l}\text { Growth-enhancing invest- } \\
\text { ment in recession countries }\end{array}$ & von Bogdandy et al., 2013 \\
\hline (D) & Tax/new own resource & EU projects & Caudal et al., 2013 \\
\cline { 3 - 4 } (E) & & (not specified) & Bénassy-Quéré et al., 2014b \\
\cline { 3 - 4 } (F) & & EU UB & Bénassy-Quéré et al., 2014a \\
\cline { 3 - 4 } (G) & Social security contributions & & Bontout and Lejeune, 2013 \\
\hline
\end{tabular}

Further dimensions in the set-up of a fiscal capacity for EMU are the possible consideration of intertemporal smoothing of area wide cyclical fluctuations via deficits, and the connection of the receipt of payments to some form of macroeconomic or fiscal conditionality.

From the characteristics of an EMU fiscal instrument considered desirable, some key questions arise. Provided that the fund is to provide for stabilisation of asymmetric shocks, is not meant to channel long-term transfers or build up structural deficits, and should be broadly balanced over time, the following issues warrant closer examination. 
To begin with, one key design feature concerns the way in which is the overall size of the budget established, and the question which size of the budget adjusts in order to balance revenue and expenditure. In versions (A) to (C), the size of the budget is established by some pre-agreed figure relative to GDP, whereas in cases (D) and (E) it would be established by the tax collected and mechanisms $(F)$ and $(\mathrm{G})$ would link the volume of the fund to individual entitlements (or Member States' rights to reclaim expenses on these). The approaches that establish the budget on the revenue side - these are versions (A) to (E) - no matter if in terms of budgetary contributions linked to macroeconomic aggregates or as tax-type payments, limit the amount of insurance that could be given and might thus not be able to provide meaningful stabilisation in the event of large shocks affecting perhaps multiple members of the euro area still asymmetrically. For approaches establishing the budget by the expenditure side, this problem is re-formulated as one of possible large longer-term transfers. For the combination of tax-type revenue with possibly individual entitlement-type expenditure, the latter will be hard to adjust: in order not to impair the extent of insurance to be provided, adjustments on the revenue side (coupled with the possibility of temporary deficits in the fund) would be preferable to limiting payments. ${ }^{5}$

Linking one side of the budget to economic outcomes that are not defined in relative terms against the euro area average, as in cases (D) to (G), entails the possibility of surpluses and deficits in the fund that would to some extent reflect the euro area economic cycle. On the other hand, because the scheme is meant to address precisely asymmetric shocks that deviate from the common cycle (which is a matter for monetary policy), inter-temporal fluctuations of resources available in the fund can be expected not to be very large. ${ }^{6}$ In addition, especially revenue or expenditure directly linked to Member States' economies at the micro level might result in asymmetries in net contributions and ultimately permanent transfers: to protect the political acceptance of the fund and avoid disincentive effects of moral hazard on economic reform, therefore, such approaches to an EU stabilisation fund will necessitate some correction mechanism. ${ }^{7}$

Another important question about the design of the mechanism is how cyclical conditions would be identified against structural developments. For those mechanisms that provide short-time redistribution across budgets, i.e. (A), (B), and (C), beyond the pros and cons of different techniques, the political problem remains that misjudging cyclical booms as higher permanent growth and failing to recognize a reduction in growth potential in time would lead to higher net claims from the fund that might be difficult to correct at a later stage. For mechanisms that link revenue or expenditure to

\footnotetext{
${ }^{5}$ See section 4 on the possibility for such a fund to operate deficits.

${ }^{6}$ Cyclical fluctuations in the euro area and participating Member States are an area of ongoing search for robust insights. Empirical research with data up until the crisis has shown that in part of the (pre-2007) euro area members economic activity fluctuates in parallel, while other countries show different, idiosyncratic business cycle patterns (for a review of empirical findings, see Giannone et al., 2010). For financial crises in general, empirical evidence shows that the volatility of economic activity as such is not altered. Again on the comovement of business cycles across euro area and EU members respectively, recent findings suggest some decoupling to have taken place (Gächter et al., 2013; Ferroni and Klaus, 2014). Most importantly, for EU countries prior to the new millennium, it has been found that around $30 \%$ of national cycles have a common, area-wide component (Croux et al., 2001). Thus the larger part of national cycles is to be addressed by specific, not common elements.

${ }^{7}$ Section 3.2.2 provides a further discussion of these issues.
} 
economic indicators at the micro level, notably (D) to $(\mathrm{G})$, the question will be how to define the revenue base or expenditure entitlements to avoid permanent flows (see again section 3.2.2). ${ }^{8}$

Yet another design question is how differences in budgetary projections and execution would be dealt with. Within the present EU budget, these differences are balanced out by ex-post GNI contributions. Planning for a budget well below the GNI expenditure ceiling allows for the ex-post respect of that ceiling also in case of adverse developments: this practice is similar to that of deliberately overconservative budgetary planning at the national level, as applied by the Netherlands. In many countries, differences between budgetary planning and execution either lead to unforeseen differences in the balance or are corrected with supplementary budgets. Such solutions do not appear acceptable for a supra-national fund that is expected not to replicate the deficit bias: therefore the fund would need some margin of uncommitted revenue supporting budgetary balance over time.

A specific possibility related to the expenditure side of an EMU stabilisation fund is that of disbursements conditional on a trigger event, such as unemployment above a pre-defined level. If rightly chosen, the trigger event could improve the ability of the mechanism to contain moral hazard by conditioning support on events exogenous to potential beneficiaries' actions (Beetsma, 1999). The technical assessments discussed in section 2.2.1 also consider the possibility of conditional mechanisms: Carnot et al. (2015) evaluate a set-up where only recessions beyond a minimum threshold are addressed, and the micro-level evaluation of unemployment insurance of Dolls et al. (2015) likewise study a contingent benefit scheme that is available only for unusually high unemployment relative to national experience: this design is found to eliminate unidirectional permanent net flows in the period studied. Both analyses confirm that such conditionality substantially lowers funding requirements: the implication for the revenue side is that a lower tax rate is required as compared with an unconditional scheme, on the same base. However, under such an approach the operation of the fund could be further away from the theoretical ideal of inter-temporal neutrality (Carnot et al., 2015).

\section{Approaches to the revenue side of fiscal union}

\subsection{Funding an EMU fiscal capacity by participating Members' budgetary contributions}

Member States' immediate contributions are a straightforward way to finance a budget for EMU. For a EMU fiscal capacity, revenue can be collected either by contributions from national budgets, some tax, or citizens' social security contributions. Disregarding complexities of definition, heterogeneity across Member States and aspects of governance ${ }^{9}$, social security contributions can also be analysed similar to taxes. Thus a basic question is if an EMU fiscal capacity is financed from vertical budgetary transfers, or a tax type instrument. Providing funding for this capacity by Member States' contributions appears to be a straightforward choice: indeed the majority of the proposals on fiscal union discussed in section 2 build on this approach, not least because debate on the revenue side of a EMU fiscal capacity has not yet gained momentum. Also this approach is characteristic of the financing of the EU

\footnotetext{
${ }^{8}$ See again section 3.2.2 on these challenges.

${ }^{9}$ Social security funds are often governed by specific bodies.
} 
budget overall, where about $70 \%$ of the EU budget are made up by Member States' contributions from national budgets established on grounds of gross national income (GNI). The large share of the GNIbased own resource in the financing of the EU budget shows its ease of handling: the revenue to be collected can be established easily. Horizontal equity across Members appears to be broadly met (in practice today, perceptions of equity are achieved by difficult negotiations of net contribution and benefit packages respectively). This approach to financing an EMU fiscal capacity would also allow introduce some stabilisation element on the revenue side, in particular by relating contributions to some business cycle indicator, albeit at the cost of introducing the ambiguity of output gaps already at the revenue side of the budget. Immediate budgetary contributions from participants of the structure imply little challenge with regard to fiscal relations across jurisdictions. Also revenue side externalities barely arise, because Member States tend to consider such contributions expenditure items, with revenue raised by own effort.

In spite of apparent ease, up-scaling country contributions to finance a EMU fiscal capacity has serious drawbacks. As expressed in the on-going debate on the reform of the own resources to the EU budget, this type of financing is unsatisfactory for a number of reasons. Notably it foregoes the opportunity to provide value added in terms improving tax systems, tax administration, and most importantly, perceptions of common good at the European level. ${ }^{10}$ From such financing, revenue side externalities barely arise, because Member States tend to consider it expenditure with revenue raised by own effort.

\subsection{Criteria for the choice of a revenue base for an EMU fiscal capacity}

\subsubsection{Revenue generating potential}

To be meaningful, a revenue base for an EMU fiscal capacity would have to generate substantial funding. Supported by back-of-the envelope-calculations, some proponents of a stabilisation fund for the euro area propose a common fund of about 1-2 \% of euro area GDP (see e.g. Wolff, 2012; Trésor, 2013; Allard et al., 2013). Allard et al. (ibid.) calculate that a fund of about 1.5 to $2.5 \%$ of euro area GDP could have provided income stabilisation in the order of smoothing about $80 \%$ of countryspecific income shocks in the euro area. In his bottom-up approach of stabilisation by a common unemployment fund, Dullien (2013) arrives at revenue needs of 0.7\% of GDP. These estimates serve as a very general point of reference when considering the potential of a revenue base for a common fund. Setting up such a fund at the EMU level would imply about a doubling of the common budgetary means at the level of the euro area. To date, the volume of the annual EU budget fluctuates around $1.15 \%$ of area wide GDP for the EU as a whole. ${ }^{11}$ At the same time, national tax collection in the EU amounts to about 40 and 26 per cent of GDP with and without social security contributions respectively. ${ }^{12}$ Thus a shift to the European level of revenue of up to 2 per cent of GDP would

\footnotetext{
${ }^{10}$ Considerations on the revenue side of a fiscal capacity for the euro area therefore show some parallelism to the ongoing discussion around the reform of the own resource system in the EU more broadly, where similar questions of Union-level value added and its visibility arise.

11 Total revenue 2013, data based on: European Commission (2013): EU budget 2013: financial report, and Eurostat, resp.

${ }^{12}$ Figures for the euro area are broadly the same; see European Commission (2014): Taxation trends in Europe, Brussels.
} 
necessitate the centralisation of up to 5 per cent of national tax revenue collections including social security, or 8 per cent of revenue without social security. A social security fund of $0.7 \%$ of GDP would require the pooling of about 3 per cent of countries' social security contributions on average. Assessments of the revenue raising potential of a number of potential bases of an EMU tax are reported in the table in the Annex.

A stabilisation fund for EMU means shifting, not expanding revenue. Thus the above figures do not imply an increase of the overall tax burden on the euro area economy. To the extent that the efficiency of public good provision is enhanced by the common instrument - notably by the very insurance mechanism or by reining in harmful tax competition -, it might include some margin for the reduction of the overall tax burden.

\subsubsection{The distribution of tax burden versus net benefits}

Taxes are non-appropriated contributions to the public budget; still their design takes note of horizontal and vertical equity. From an economic point of view, a key distinctive characteristic of taxes against other types of payment like charges or fees is non-appropriation to specific spending purposes. In practice however, the design of net contributions and benefits via tax systems is shaped by the principles of horizontal and vertical equity. Horizontal equity corresponds to the benefit principle and requires some match of taxpayers (by sector or jurisdiction) and the beneficiaries of expenditure, supporting some combinations of revenue and expenditure against others. Vertical equity requires those who are more able to shoulder a higher tax burden. Horizontal equity appears to be at odds with the key characteristic of taxes of not being tied to specific benefits. National tax systems provide a balance between these two principles and the nature of taxes as non-appropriated revenue in line with prevailing norms.

As regards principles to tax systems, non-appropriation does not apply to an EMU stabilisation capacity, because the mechanism is limited to the euro area members that do not share other common fiscal instruments. In principle the fund could be open to non-euro area EU countries as well. Indeed at first sight it appears straightforward that, as economic integration within the euro area supports business cycle synchronisation, members against non-members of the euro area are more suited to provide insurance to each other. This is very unlikely to happen, however. Adopting a common instrument to insure against asymmetric economic shocks would be a major step in economic policy integration. The euro area members with better adjustment capability have been hesitant to rush forward with the construction of such an instrument: it is understood that for political acceptability, the design of the instrument must limit moral hazard to the highest possible degree, i.e. it must not slow down participating countries' efforts to undertake structural reform to build more resilient economies. The consideration of this challenge has fed the 'Five presidents' report' (Juncker et al., 2015) to propose the achievement of a certain degree of convergence of the participating economies in terms of economic resilience as a pre-condition to acceding a common fiscal risk-sharing instrument. If Member States outside the euro area are ready to undergo the necessary reform, they might be ready to adopt the euro just as well. ${ }^{13}$ Besides, the value of fiscal stabilisation in the advent of idiosyncratic

\footnotetext{
${ }^{13}$ The formulation of requirements for entry to a EMU fiscal instrument notwithstanding, the reversibility of reform in participating countries might still remain a challenge that has not received attention in the debate so
} 
shocks is arguably higher for Member States that have foregone an independent monetary policy (while it would remain in the remit of monetary policy to fend off the effects of area-wide shocks) ${ }^{14}$. Therefore it is unlikely to expect that non-euro area EU Members would want to join a risk-sharing fund, even if this would be admitted. Hence the fiscal stabilisation instrument would be used by a specific sub-set of EU Members: as long as this particular group does not establish other instruments, there would be an immediate correspondence of a revenue stream to a spending item. ${ }^{15}$

Concerning the financing of an EMU fiscal capacity, vertical equity - i.e. higher contributions by economically more successful members - is ruled out politically. Sound economic rationale for doing so is given by the risk of moral hazard: smoothing negative shocks to income might dis-incentivise governments to raise their economies' self-healing capability and deteriorate economic outcomes overall. In relation to the participating countries, this leaves horizontal equity to remain the guiding principle for the operation of the fund. Making sure that the fund complies with this principle is in practice far from trivial however, even in the simplest case of a transfer mechanism across national budgets as put forward in proposals (A) and (B) reviewed in section 2.1.

Notably depending on the specific approach taken, there are several fundamental challenges: first, no matter what indicator of activity is chosen to identify the position of a country with respect to the fund, the separation of temporary fluctuations from permanent structural differences across participating economies remains difficult. For the approach of am EMU-level unemployment insurance, the condition to address temporary, cyclical difficulties implies that only short-term unemployment would be supported by benefits, leaving it entirely to Member States to deal with long-term unemployment that is rather related to structural inefficiencies. Depending on the duration of payments as well as country-specific patterns of job separations and firm deaths, this approach might even reward the more flexible economies where market forces do a better job of Schumpeterian creative destruction. However, even with a focus on short-term unemployment, permanent transfers might arise ex-post. Studying different designs of an EMU-level unemployment insurance scheme with short-term duration of payments, Dolls et al. (2015) show that in 2000-2013, several EMU Members would have been either permanent net contributors or permanent net recipients with respect to the common scheme. The problem of separating temporary from permanent components of the economies is present in 'macro' schemes building on some aggregate measures as well. In the case of the output gap as the most encompassing measure of cyclical developments, differences between real time estimates and later revisions pose a particular challenge, even if methodologies are constantly improved; to date, the output gap tends to be underestimated in particular during upswings, which disturbs symmetry in a fund with output gap-related payments (Carnot et al., 2015). Furthermore, the possible asymmetry of business cycles implies an additional source of non-zero net payments in the medium term, even in an ex ante transfer-neutral scheme based on output gaps. ${ }^{16}$ Participating countries' budgetary positions

far. In any event, the design will have to make sure not to create large net payments ex post: this will necessitate a claw-back mechanism that can be activated if necessary.

${ }^{14}$ Carnot et al. (2015) consider the possibility to provide inter-temporal insurance to area-wide shocks by a common rainy day fund as well, specifically as large negative output gaps tend to confront monetary policy with the zero lower bound constraint. However they note that this avenue might provide a slippery slope toward undermining fiscal discipline, and interfere with aggregate demand management pursued by the European Central Bank.

15 The technical possibility to do so in the EU budgetary framework is explained in section 4.

${ }^{16}$ In this context, asymmetry refers to the temporal profile of the fluctuations in economic activity in one country relative to peaks and troughs, not to the decoupling of business cycles across different countries. 
vis-à-vis the fund could also be based on some unemployment rate, or its change. For euro area unemployment rates, the difference between the first estimate and the one made 12 months later amounts to 0.15 percentage point (Bontout and Lejeune, 2013). The problem of data revisions is not present with contributions or benefits that are immediately linked to economic agents - such as by payments to individuals, not to national budgets - , and this latter approach also has the advantage of providing stabilisation with lesser delay of implementation. ${ }^{17}$

Overall, these technical challenges will more closely relate to the design of the expenditure side of a common insurance mechanism. However, contributions directly related to economic activity will have specific challenges to the revenue side of their own. In the case of revenue from corporate income taxation, relatively higher contributions to the fund will flow from countries with higher rates of incorporation and larger and more profitable corporations, even if the tax is levied on a common uniform base - while incorporation might be driven by the national corporate income tax rate applied in participating members (de Mooij and Nicodème, 2006). ${ }^{18}$ In the case of individual contributions to an EMU-wide unemployment fund, there will be also characteristic differences in national revenue contributions, depending on design, specifically as regards the inclusion of self-employed individuals. To provide for uniform relative shock-absorption capacity, with genuine tax-type revenue bases, the challenge will be to broadly match the revenue rising capacity of national bases to the amplitude of a typical asymmetric shock. Because apart from a budgetary transfer mechanism, no real-word tax base will fully comply with the theoretical ideal, this consideration leads to the questions on the side that determines the budget, the need of an equilibrating mechanism, and the volatility of resources available in the fund (see sections 3.2.5 and 4).

In any event, national contributions to the fund raised by taxes will fluctuate with country-specific cyclical conditions (see section 3.2.5). Due to the deviations from the principle of horizontal equity stemming from either the revenue or the expenditure side, to exclude the outcome of permanent transfers ex-post, the definition of a claw-back mechanism will be inevitable. It could e.g. take the form of revenue rebates or surcharges in case of long-run disequilibrium of in- and outflows by countries (see e.g. Dolls et al., 2015), or the adjustment of drawing rates on expenditure from the stabilisation fund (the latter would be difficult though if payments are related to individual entitlements, notably short-term unemployment benefits). Enforceable claw-back mechanisms will be important to avoid the ex-post open-endedness of insurance arrangements while allowing the factual amount of insurance given to accommodate also large shocks.

\footnotetext{
${ }^{17}$ Still, depending on the approach taken, there will be some deviation between the economic cycle and net flows from the fund, to the extent that the indicator triggering the flows - even if automatic and linked to individual entitlements - is lagging relative to the cycle.

${ }^{18}$ To what extent corporate income taxation-based contributions to an EMU stabilisation fund would be asymmetric cannot be assessed to date. At present (2014), in the euro area overall, revenue amounting to $2.4 \%$ of GDP has been raised from corporate income taxation (including holding gains (Eurostat, 2015). However there are large national differences in corporate income tax (CIT) revenue, with Latvia and Lithuania collecting about $1.5 \%$ of GDP ${ }^{18}$; Estonia collects just about $0.5 \%$ of GDP by CIT - albeit excluding holding gains (there are no data on the latter); and CIT revenue amounts to $6.5 \%$ of GDP in Cyprus and Malta. If difficult calculations as for the "VAT own resource" to the EU were to be avoided i.e. if it were to be established that a specific percentage of CIT revenue automatically goes to the EMU fund, a common definition of the base appears inevitable. Such a base would, however, obviously deviate from the CIT bases as defined in EU Members to date. For the adoption of a common corporate tax base in EU Members, Spengel et al. (2008) find that the values of the tax base would increase in all countries but Cyprus and Ireland. The study does not consider the possibilities of cross-border compensation and loss compensation - that are defining elements of the reform debate to date - however.
} 
An example of how the elimination of long-term imbalances might operate is provided by the federal unemployment trust fund operated in the United States: there, States are building up accounts during good times and draw from them during downturns to provide unemployment benefits. States might also record deficits at the fund, but these need to be repaid (with interest) within two years; nonrepayment will automatically trigger higher federal taxes raised from the respective State (Bontout and Lejeune, 2013). However, this scheme in principle amounts to enforced rainy day funds for the participating States, without exploiting the benefits of insurance. The insurance mechanism would, however, have merits of its own. In the framework of budgetary arrangements of the EU, the excessive focus on horizontal equity among EU Members expressed in the idea of "fair return" has been identified to be one of the central flaws (see section 3.2.3). An insurance-type fiscal stabilisation capacity provides an interesting avenue for the provision of EMU-level value added while preserving horizontal equity: moving away from cross-country horizontal equity at any point of time, it would allow horizontal equity across countries over time and render tangible benefits to specific countries in times of need at the same time. This requires that deviation of a country's position from budgetary neutrality be admissible free of interest for some period (i.e. the fund should not operate as a set of country-specific rainy day funds). It is a matter of political discretion to establish the maximum period after which transfers to countries would be considered permanent, activating a claw-back rule.

\subsubsection{Visibility and a strengthened link between the $\mathrm{EU}$ and the citizens}

Visible value added and a strengthened link between citizens and the EU is the first priority to any EU budgetary reform: a new EMU stabilisation capacity provides an opportunity to this end. In the Blueprint timeline, measures to deepen accountability and democratic legitimacy are foreseen to accompany the process towards genuine economic union in all stages. This meets the truth that EU institutions do not score high in citizens' perceptions, which points at shortcomings of output legitimacy of EU policies. Among others, citizens have gross misperceptions of the EU budget and EU spending (TNS Opinion \& Social, 2011) ${ }^{19}$. Therefore, for any further common budgetary means, it is essential that the value added is broadly recognized and attributed to the Union.

The addressing of the shortcomings of legitimacy at the EU level calls for a social contract approach, specifically in view of deepening EMU. Highlights of legitimacy, accountability and public support in the Blueprint and Four and Five Presidents' Reports respectively correspond to a contractarian approach to sovereign activity, according to which such activity is legitimized by the voice, support, and scrutiny of appropriate representations of citizenry. Social contracts are sets of relations linking citizens with governments and each other. Important elements are rights and responsibilities, commonly shared norms to limit free-riding, a willingness to share beyond the logic of fair individual return based on an understanding of cooperation, and institutions to balance divergent claims, which

19 Specifically, $44 \%$ of the surveyed agreed that the EU budget "gives poor value for money for EU citizens", against $27 \%$ in favour of "good value for money". Also there is a remarkable lack of knowledge about the areas of present EU spending: a relative majority, 32\%, think that the EU budget is primarily spent on the administrative costs of staff and buildings, while this heading makes up less than $6 \%$ of the EU budget. Respondents' preferences on areas no which allocate most of EU funding put social welfare and employment first (42\% of respondents), followed by economic growth (40\%). Finally it has to be noted that $47 \%$, a majority, agree that "the political objectives of the EU do not justify an increase in the Union's budget: confirming that any consideration of budgetary reform or fiscal instruments at the EU level has to put key emphasis on strengthening European integration along the political dimension. 
cannot be done by an accounting approach. Seemingly in contradiction with the intellectual origins of the approach, because rights and obligations can never be fully spelled out and enforced, trust in institutions is an important pre-requisite to the flexibility and stability of entities held together by social contract. In the contractarian tradition, social contracts legitimize government action, define its scope, and serve as implicit yardsticks for evaluation. Failure against the expectations embodied in social contracts prompts a crisis of legitimacy. The sovereign debt crisis in EMU disappointed important social expectations of affected populations: namely of rapidly growing well-being beyond external financing constraints in some Members, and of no mutualisation of debt obligations in others: in fact the crisis showed that these expectations were inconsistent with each other and more generally that the social contract underlying EMU may not have been sufficiently developed. From this perspective, in the search of measures to fix the oft-invoked incompleteness of monetary without fiscal union, a technical approach to the mechanics of economic rebalancing may not be sufficient. The broader perspective of social contracts instead implies the priority of developing the link between the governance structure and the citizens.

One priority derived from the social contracts perspective on the revenue side of an EMU budget is that of a genuine own resource. ${ }^{20} \mathrm{~A}$ tax-type own resources is preferable to payment mechanisms across national budgets, because the perception of budgetary means of the EU as membership fee-type contributions and expectations of fair return is inimical to the social contracts view. Indeed the shortcomings in perceived output legitimacy of EU policies and trust in EU institutions can also be traced back to the current state of genuine own resources of the Union: EU level policy-making is indeed "representation without taxation". Developing a fiscal instrument linking citizens and the supranational government also on the revenue side might provide a boost of awareness of policies at the European level, improved translation of citizens' preferences in the policy process, and improved scrutiny and accountability, thereby providing impulses to a genuine social contract underpinning EMU. ${ }^{21}$ From this perspective, the introduction of an "EMU tax" should not be seen as something to avoid and a challenge to the political viability of an EMU-level fiscal stabilisation capacity, but on the contrary, as an opportunity to raise awareness of the value added flowing from the new instrument. These considerations support an approach to continuously levy revenue to the fund from participating Member States, not only from those in exceptionally good cyclical conditions, as suggested by Carnot et al. (2015).

The choice of the revenue base provides a further opportunity to develop the social contract framing EMU. Notably appetite for a EMU stabilisation function could be seized to strengthen the output legitimacy of EU policies by improved response to claims that have been underserved by the European policy framework so far. In this regard, it deserves consideration that in the past two decades, integration dynamics in the EU have been chiefly derived from completing the internal market and enforcing the "four freedoms", while the build-up of governance structures to address expectations of the public beyond this agenda have not kept pace (Scharpf, 2009). What is more, the Troika adjustment programmes have been perceived by many critics to have provided the pretext to the razing

20 The social contracts approach also implications on the design of a EMU fiscal capacity on the expenditure side, however exploring these is beyond the scope of this analysis.

21 Likewise, this argument suggests that some direct stabilisation instrument - such as individual unemployment benefits - is preferable to support into national budgets for output smoothing in case of an asymmetric shock. 
of collective governance arrangements to within countries beyond necessity to unilaterally advance market integration. Whether or not these claims can be supported by facts, many of the structural reforms adopted during the euro area crisis have put insider employees at a disadvantage against owners of capital without policy commitment to share the rents from these reforms (Grüner, 2013): hence they have favoured citizens with preferences for better conditions for the mobility of production factors over those who derive individual benefits from less market integration and flexibility. The interests of these latter populations cannot be served without foregoing benefits of international cooperation: however, in the sake of a balanced approach toward different interests among EU citizens, next steps to the deepening EMU might consider eliminating negative externalities to welfare created by economic integration. With regard to revenue, an obvious policy candidate would be to rein in the negative externalities of tax competition.

The above arguments to deepen social contract at the European level can be given strength by recognizing degrees of freedom around an EMU fiscal capacity. The incomplete social contract at the European level expressed in the shortcomings of perceived legitimacy rests on the fact that European federalism is a bottom-up system where sovereign functions at the central level are underdeveloped relative to other federations. Member States' political appetite for a new function to the EU budget available to EMU members provides a window of opportunity to strengthen these functions more broadly. Indeed as argued above, from a legitimacy perspective, doing so should clearly enjoy priority over a purely technical approach to budgetary stabilisation. In this regard it is useful to recognize that fiscal union is by no means as inevitable a condition for a monetary union as some policy analysts like to present it (von Hagen, 2014). Hence the quest for the improvement of democratically legitimized governance structures instead of creating entirely technical accounting structures suggests an approach of "no EMU stabilisation without taxation".

The micro approach to fiscal stabilisation by unemployment insurance financed by individual contributions has special appeal to strengthen the social contract dimension of EMU. Such a mechanism creates a clear and direct link between individuals and the EU level of governance both on the revenue and expenditure side, with unshared accountability. Furthermore, the mechanism would directly address the shortcomings of output legitimacy in areas other than market integration and foster social contract by common norms of social protection in this area. Other possible bases also carry potential with regard to value added, as summarized in the table in the Annex.

\subsubsection{Fiscal relations across jurisdictions}

A key aspect of multi-layered fiscal structures is fiscal respectively tax competition and cooperation. Competences and constraints on the choice of the tax base and rate produce different settings of horizontal or vertical tax competition and bear different implications in this regard. Effects of establishing a common revenue base for EMU cannot be expected to be large but should be considered nevertheless.

Base sharing between the Union and the Member States could counteract horizontal tax competition, but has no relevance in the budgetary framework of the EU. Vertical tax competition arises with tax sharing by different levels of jurisdictions. This can take two forms: base sharing with independent powers to legislate rates, or revenue sharing where one level retains the right to legislate the rate (an example is the VAT own resource). With autonomous tax-setting powers of jurisdictions over the same base, the tax burden would be too high because the jurisdictions would consider distortions from 
taxation only relative to their part in revenue, not the full amount. This might indeed be useful to mitigate harmful horizontal competition if present. In the sui generis framework of European federalism, base sharing is far from reality however: to date, the right to legislate on Union revenue is ruled by unanimity in the Council. Therefore, the institutional set-up of revenue policy can better be described as tax coordination of sub-federal sovereigns than vertical differentiation of fiscal sovereignty.

Fully suppressing horizontal tax competition means a single base and rates: this is neither desirable nor realistic for many bases. Some flexibility in the choice of rates might be desirable to accommodate heterogeneity in the quality and quantity of public goods. Thus the case for a centralised tax with uniform rates can at most be made for bases where the tax does not have to counterbalance other locational choice criteria of economic agents. Besides, any base with an established role in national tax systems is unlikely to be fully conferred to the Union. This consideration rules out unshared EMU revenue from greenhouse emission rights. ${ }^{22}$ An obvious candidate, instead, would be the taxation of the financial sector in a unified regulatory, supervision and resolution framework. Among the Member States, arrangements of financial sector taxation are not yet fully hammered out, which leaves scope for considering the financial sector to generate revenue for EMU stabilisation policies. ${ }^{23}$ On the other hand, euro area banks are expected to contribute by ex-ante payments to the funding of the common bank resolution fund at EMU level; other areas of public spending would come second after this objective. It is unlikely that overall burdens on the financial sector can be increased in the short run such that funding needs for financial and macroeconomic stability can both be served at the same time. In addition to political economy challenges, such an increase might also have negative implications on macroeconomic performance.

Revenue sharing on a harmonized base could mitigate horizontal tax competition, leave flexibility for Member States, improve the efficiency of resource allocation, and decrease the cost of compliance for internationally mobile taxpayers. This possibility concerns a uniform definition of the tax base across Members, a uniform rate for revenue to the Union, and country-specific surtax rates for Member States' revenue. The VAT own resource is an example, albeit one where tax competition does not play a role: 0.3 percentage point of VAT revenue collected nationally ${ }^{24}$ on a fairly harmonised base with rates chosen by Member States within a commonly agreed band goes to the EU budget. In general, arrangements as described above define a minimum tax rate for a harmonized base that might indeed be higher than the lowest rate in force. Rate setting by individual countries in this framework ignores

22 Presently, under the Emissions Trading System (ETS), emission allowances are given away for free or by auctioning by national governments. Auctioning has started in 2013; the free allotment of greenhouse gas emission rights, exclusively in use since the establishment of the policy in 2005 until 2012, is set to be phased out in 2027. Thus, the role of ETS revenue for Member States' budgets small to date but will increase in the next few years: this appears to make ETS auction receipts a useful candidate for exclusive Union revenue. However, ETS revenue is earmarked for climate action. This arrangement supports cooperation in an area difficult enough to establish. In order not to jeopardize this success of a common approach, revenue for the euro area could only come on top of the revenue projected for national budgets, i.e. by increasing the tax burden on greenhouse gas emissions under a regime of revenue sharing between Members and the euro area.

23 To date, some Member States are introducing bank levies to feed bank resolution funds, but no link has been made so far between financial sector taxation other than these levies and resolution funds: FTT or similar revenue is thus not pre-committed to the financing of financial stability.

24 There are reduced VAT call rates for Austria (0.225), Germany (0.15), and the Netherlands and Sweden $(0.1)$. 
the externality from distortionary taxation on revenue to the federal jurisdiction and thereby provides for some correction against horizontal tax competition. On the other hand, the transparency and ease of comparison of tax burdens with a harmonized base might intensify horizontal tax competition. On the positive side, a harmonised base facilitates compliance for internationally active subjects. In practice, any base could serve for revenue sharing, but with regard to curbing horizontal tax competition and improving compliance costs, corporate taxation would be a natural candidate. One possible starting point for this avenue could be the Commission's proposal for a common consolidated corporate tax base (CCCTB). Revenue sharing on a common base could apply e.g. to labour income taxation, possibly to finance a common unemployment benefit system, as well: but here much work lies ahead to define the common base. Furthermore, labour mobility is not yet high enough in EMU to feed concerns about under-taxation of mobile bases. Revenue sharing could finally also apply to financial sector taxation, which would necessitate a common base as well.

A tax base that would curb horizontal tax competition appears to kill two birds with one stone and has hence particular appeal in EMU. Horizontal tax competition pertains to mobile tax bases, capital and corporate taxation being affected most: the careful and extensive recent review of empirical studies by Devereux and Loretz (2012) leads the authors to conclude that empirical evidence clearly supports downward pressure on corporate taxation from tax competition, that has been especially strong in the EU and has taken further impetus by the tax setting of the small new EU entrants in the last decade. There is some rationale for differences in corporate tax rates across jurisdictions in line with differences in the benefit packages offered to corporate activity, but overall the tendency of downward pressure on effective corporate tax rates is problematic: it might violate the benefit principle, and, via the backstop function of the statutory CIT rate to personal income taxation more broadly, it might ultimately limit the capacity of sovereign states for redistribution and the accommodation of preferences of public goods provision. ${ }^{25}$ Tax competition can be assumed to be even more intense in EMU, as the absence of exchange rate risk is conducive to capital mobility. ${ }^{26}$ The Commission's relaunch of its proposal to establish a common base to corporate taxation in June 2015, this time to make it mandatory to corporations, has also been motivated precisely by the evidence of under-taxation of

25 The welfare implications of tax competition are not straightforward: their evaluation ultimately depends on the assumptions taken on the behaviour of government (Edwards and Keen, 1996). Proponents of the view of the state as a Leviathan maximising its power to the detriment of citizens' welfare cherish the disciplining effect on of downward pressure on corporate income taxation on governments. Concomitant to the finding of tax competition however, in the EU, overall tax burdens in EU Members have remained broadly stable in the past two decades (European Commission, 2014). This puts into question if tax competition specifically concerning mobile bases is overall welfare improving: it rather appears that locationally mobile corporations are able to decrease their tax burden independently from the bundle of public goods offered to them, which might then be cross-subsidized by immobile taxpayers, raising the question of equity in the sense of the benefit principle. Indeed it is questionable why to expect the efficiency- and welfare-improving impact on the tax system to arise from tax competition on a narrow subset of the bases of overall taxation, while leaving specialised institutions in advanced democracies mandated with the scrutiny of public spending, such as national parliaments, courts of audit, and taxpayers' associations, out of regard.

26 To the extent that labour becomes more sensitive to economic conditions with deepening integration as well, horizontal competition of jurisdictions might also increasingly affect the taxation of labour and put additional pressure on Member States to finance public goods. 
corporate income in the EU. ${ }^{27}$ Reining in tax competition in the area of corporate taxation has advantages further to revenue potential without efficiency loss, as outlined in section 3.2.3.

\subsubsection{Properties over the cycle}

Cyclicality is another dimension of a revenue base with different mechanisms to consider. At the revenue side, automatic stabilisers contribute to attenuating the volatility of economic activity through several channels (McKay and Reis, 2013): first, they stabilise consumption demand, as proportional taxation attenuates disposable income volatility in absolute terms, while progressive taxation does so over-proportionally. Next, progressive tax schemes imply different marginal incentives over the cycle: the anti-cyclical effects of progressive personal income taxation on labour supply are a case in point. It has also been argued that redistributive properties of tax systems add to stabilisation via their differential impact on income groups, including the alleviation of constraints to adjustment. Strong demand stabilisation effects are also found for corporate income taxation, in particular in the presence of credit constraints to enterprises, and with particular relevance during downturns (Buettner and Fuest, 2010).

To fund a EMU fiscal capacity, different impacts of cyclically sensitive revenue are relevant. The choice of a cyclically responsive revenue item for a EMU stabilisation capacity adds to the redistribution of fiscal effort across the participating members already at the revenue side. Differences in the volatility of revenue across countries should not be a problem overall, especially if there is some accounting mechanism to keep the fund non-redistributive. If the mitigation of harmful tax competition allows a shift in the overall structure of taxation to a cyclically more sensitive base, this might improve the overall stabilisation properties of tax systems in the participating countries. What is more, shifting volatile revenue to the EU level would allow for higher volatility overall revenue collected in a country, still under compliance with the EU limit to deficits. At the same time, cyclically more sensitive items make EMU-wide economic fluctuations more felt in the common fund. Although the function of a EMU fiscal capacity would be to provide stabilisation of asymmetric shocks relative to area-wide developments, such cyclical variations of overall revenue would require some balancing mechanism for the fund over time.

\subsubsection{Need to adjust national tax systems}

Different bases for revenue for a tax at the EMU level entail the need for adjustments in national tax systems to different degrees. Tapping a base generating zero or little revenue to date, e.g. the Emissions Trading System or the FTT, would not create direct changes in the base composition of national revenue. Because the purpose of an EMU fiscal fund would be only that of risk sharing and not one of expanding public budgets, revenue neutrality would necessitate counterbalancing adjustments of national tax systems. With revenue sharing from an already harmonized base, e.g. VAT, this is trivially achieved if overall taxation of the base is kept unchanged. When the tax also addresses harmful tax competition and thereby improves the efficiency of taxation of a specific sector, increasing overall revenue would be possible. Another possibility is to contribute to tax shift by

27 Since the 2011 launch of its proposal on a Common Consolidated Corporate Tax Base, the European Commission's position has been to distance itself from the consideration of this base for an "own resource (European Commission, 2011). 
increasing the overall taxation of indirect bases identified as growth-friendly or contributing to other shared policy objectives, such as VAT or energy, while allowing Member States to alleviate the taxation of other bases in line with the recommendations on tax shift.

An income type base for EU revenue (such as corporate profits, or wages) would necessitate more difficult changes in national tax systems. For example, corporate taxation is one element in a more complex framework of domestic capital income taxation that conceptually includes interest incomes, dividend incomes, and capital gains. In this regard, EU Members display considerable diversity (Schratzenstaller, 2004). Harmonizing the base for corporate taxation across EMU members would necessitate some adjustment of national tax systems along these elements as well.

\section{$4 \quad$ How to organise a budget for EMU?}

On the design of budgetary arrangements to accommodate a EMU fiscal capacity, there are several requirements. An important question in the reflections on a fiscal capacity for EMU is if, or how, a budget for EMU could be organised within the present institutional framework. From a perspective committed to the Community method, this entails the objective to place a stabilisation capacity for EMU within the EU budget. Such a new fund - ideally as a part of the EU budget - would need to meet several criteria. In particular, it would pertain to EMU Members only. This would apply to revenue as well as expenditure, implying revenue assignment in a broader budget framework. Furthermore, as said, any new budgetary mechanism should serve the overarching objective to enhance the visibility of European value added and support the legitimacy of EU policies.

Creating an EMU fund outside the EU budget would be straightforward but not the best choice from an institutional point of view. A cornerstone in the budgetary architecture of the EU is the principle of the unity of the EU budget, serving the key purpose to maintain the powers of scrutiny of the European Parliament. This principle suggests priority to the allocation within the EU budget of any new fund. Exceptions are possible with appropriate safeguards of the European Parliament's budgetary control rights. In particular, exceptions to date are based on the legal personality of a body that is different from the Union, or on the division of competences between the Union and the Members (Repasi, 2013). ${ }^{28}$ Establishing a fund centralising and redistributing revenue from and to national budgets respectively as an intergovernmental tool, outside the EU budget, would be technically the least challenging way to provide for stabilisation in EMU. An additional advantage would be that such horizontal transfers would leave the volume of the EU budget unaffected. However, this would add to institutional fragmentation, feed perceptions of complexity, and thereby contradict the objective to make European value added easier to experience and account for. Thus, as a general rule, a fund would preferably be part of the EU budget; if not, the discharge rights of the European Parliament would have to be ensured.

28 Concerning the of legal grounds for the establishment of an EMU fund either within or outside the EU budget, legal analysis asserts that the distinction if the functions of a EMU fund would or would not undermine existing EU initiatives could only be done on the basis of specific proposals. Placing the EMU fund outside the EU budget is only be possible on condition that these functions do not undermine existing EU initiatives (Repasi, 2013). 
The allocation of an EMU fund within the EU budgetary framework is also one of competence. The principle of unity of the EU budget gives priority to the consideration of an EMU fund as part of the EU budget to the extent that this fund would relate to existing competences of the Union, including shared competences with Member States. According to legal analysis, the functions of the fiscal capacity proposed by the President of the European Council would partly fall within the EU's shared competence on social and territorial cohesion (Repasi, 2013). ${ }^{29}$

Technical challenges to establish a EMU fiscal capacity within the EU budget are surmountable: the main difficulty appears to be political. Rules governing the EU budget to date allow for the establishment of a new budget heading to the benefit of some, not all, EU Members, cohesion policy being an obvious example. The assignment of revenue to a specific budget line is likewise possible, an example being revenue from the corrective arm of the Stability and Growth Pact being assigned to the European Financial Stability Facility (EFSF). Such assigned revenue has the additional attraction that it does not fall under the GNI budgetary ceilings established by the Own resource regulation and thereby has no technical and only indirect political relevance for these ceilings. ${ }^{30}$ While the EU budget is entirely being funded by so-called own resources of different categories, the Union may establish a new category of own resources that would be financed by contributions of some Member States with a higher rate, including the possibility of zero contributions by the Members not having joined EMU. ${ }^{31}$ Obviously within the EU budget an EMU fund would have to be financed by a new category of own resource. Introducing a new own resource would have to be adopted under unanimity and approved by Members in accordance with their constitutional requirements (Art. 311 TFEU). This provides nonEU Members, including those with a permanent derogation, with a strong position when seeking agreement, which they might welcome to prevent a scenario of 'two-speed Europe'. Also stakes of pre-ins in the definition of EMU revenues might shift the balance between desired solidarity components and preconditions attached to a new EU instrument.

A fiscal capacity for EMU to serve the purpose of stabilisation would bring the new element of cyclicality into the EU budget. To date, cyclical economic fluctuations have had relatively little impact on the EU budget. Most of the budget is subject to a multiannual financial planning framework set out in absolute terms; by its nature, expenditure requires only little adjustments to cyclical developments. Balancing the budget is done via adjustments of the GNI own resource, where the planned budget leaves a sufficient margin against the own resource ceiling. Although the financial programming of the EU is placed into a relatively static, medium-term framework, more cyclical revenue or spending could still be easily integrated into the EU budget because items financed by assigned revenue are not covered by the multi-annual financial framework. With assigned revenue and an own budget heading

29 As concerns discretionary stabilisation policy specifically, such policy has already been exercised at the Union level, albeit in a spontaneous and non-systematic manner. Notably, the European Economic Recovery Plan had a distinctive EU component with financing from the EU budget; also amendments to the implementation of cohesion policy spending served stabilisation purposes. See European Commission (2011), A budget for EU2020, p. 11f.

30 The GNI ceilings for commitment and payment appropriations are set in the Own resource regulation, the amendment of which requires unanimity and ratification according to national procedures.

31 The introduction of an own resource necessitating base harmonisation does not appear incompatible with this perspective. In the EU non-members, the common base could theoretically coexist with the national base but not serve for taxation; taxation would shift to the new base with EMU entry. Maintaining two sets of rules for one and the same source of revenue would obviously have too high administration costs and is not a useful long-run option e.g. in case of corporate tax revenue for EMU. 
for EMU, the fiscal capacity could form a distinct part within the EU budget. For this distinct unit, the question remains which part of the budget would define its volume and which would adjust. Revenue other than GNI contributions and expenditure linked to individual or national entitlements sensitive to cyclical conditions would obviously create the need of some balancing of the budget over time by borrowing, or balancing of the residual via GNI contributions. This possibility would be in particular important to allow the insurance given to accommodate especially large shocks for which the revenue side of the fund has not catered for by design. ${ }^{32}$ In fact while borrowing cannot serve to contribute to the general budget, borrowing and lending for specific purposes is permissible; guarantees backing such borrowing are considered in the overall budgetary framework.

If restricted to case-by-case support in the presence of deep recessions, special instruments available to the EU at present might provide interesting models to provide for EMU solidarity for stabilisation. Special instruments available to react to unforeseen circumstances include the Emergency Aid Reserve, the European Union Solidarity Fund, and the Flexibility Instrument, all not being part of the MFF. A limited version of an EMU fiscal capacity could foresee such a common fund - a form of EMU wide rainy day fund - available to Members suffering from deep GDP shortfalls. ${ }^{33}$

\section{Conclusion}

There is some political appetite to consider stabilisation in EMU provided at the central level. Academic and policy contributions reflect a certain demand for extending the scope of EU level public goods to risk-sharing of asymmetric macroeconomic shocks. Until most recently, to date there has been little consideration to the revenue side so far.

This analysis has provided food for thought to the search of a revenue instrument in case deepening EMU on the fiscal side is pursued. GNI-type contributions to feed such a budget would be most straightforward and easy to handle, but would dismiss the chance of a shift toward creating more tangible links between citizens and the EU level as well as tangible value added. Against this background, we argue that a fiscal instrument for EMU would provide the opportunity to address harmful tax competition and thereby improve the output legitimacy of EU policies as well. Indeed in the present institutional set-up of the EU, the most realistic form of fiscal relations to provide revenue for EMU is that of revenue sharing on a harmonized base, which would have the potential to mitigate tax competition across EMU members. Besides if kept redistribution neutral in the longer term, precisely by adding a new function addressing cyclical movements into the EU budgetary framework, an EMU fiscal capacity might have the benefit of providing value added and strictly complying with horizontal equity among participating members at the same time. Depending on the approaches to its spending as well as the revenue side, an EMU fiscal instrument would bring in elements of cyclicality

\footnotetext{
${ }^{32}$ For such events, a claw-back mechanism (as discussed in section 3.2.2) will be yet again particularly important notably to avoid permanent net flows to emerge.

33 In terms of budgetary consequences, there is some parallelism between natural disasters and large-scale recessions. This is reflected in the coverage of both conditions by escape clauses within national budget balance rules to allow setting them temporarily out of operation without compromising their effectiveness.
} 
into the EU budget. These aspects, as well as those of implications of a new EU level fund on national tax structures and the tax mix, also need consideration.

According to first analysis, legal and technical possibilities allow allocate an EMU fiscal capacity within the EU budget. Doing so would be important for compliance with the unity of the EU budget, a cornerstone of EU budgetary principles. As suggested by available expert analysis, technical challenges of accompanying the characteristics of such a fund - cyclical volatility, restrictions to a subset of EU Members, and the possible establishment of the size of the fund by individual entitlements - do not appear insurmountable.

An aspect outside the scope of this analysis is that of tax administration. To the extent that EU revenue is collected from a shared, harmonised base, revenue collection will primarily rest in the hands of national authorities. Indeed at the EU level such competences and capacities are neither available nor necessary. However, even although the redistributive features of an EMU fiscal instrument over time could be limited by appropriate correction elements, the assignment of revenue to EMU from a taxtype base provides the case for better cooperation among participating members in tax administration matters as well as a role for the EU level in monitoring and fostering the enforcement of high tax compliance by national authorities. This could bring the additional benefit of improvement in tax collection systems and practices in countries where the scope to do so exists.

\section{References}

Allard, Céline, Petya Koeva Brooks, John C. Bluedorn, Fabian Bornhorst, Katharine Christopherson, Franziska Ohnsorge, Tigran Poghosyan, and an IMF Staff Team (2013), Toward a fiscal union for the euro area, IMF Staff Discussion Note SDN/13/09, Washington, D.C.

Asdrubali, Pierfederico, Bent Sørensen, and Oved Yosha (1996), Channels of interstate risk sharing: United States 1963-1990, Quarterly Journal of Economics 111 (4): 1081-1110.

Beetsma, Roel (1999), How to deal with asymmetric shocks under European Monetary Union? Paper prepared for the Flemish economic conference "EMU: The challenge", Ghent, 17-18 March 2000, mimeo.

Begg, Ian (2011): An EU tax: overdne reform or federalist fantasy?, Friedrich-Ebert-Stiftung, policy paper.

Bénassy-Quéré, Agnès, Yves Bertoncini, Jean-Louis Bianco, Laurence Boone, Bertrand Dumont, Sylvie Goluard, André Loesekrug-Pietri, Rostane Mehdi, Etienne Pflimlin, Denis Simonneau, Carole Ulmer, et Shahin Vallée (2014a), For a Euro Community, Bruegel.

Bénassy-Quéré, Agnès, Alain Trannoy, and Guntram Wolff (2014b), Tax harmonisation in Europe: moving forward, Les notes du conseil d'analyse économique no. 14, Paris.

von Bogdandy, Armin, Christian Calliess, Henrik Enderlein, Marcel Fratzscher, Clemens Fuest, Franz C. Mayer, Daniela Schwarzer, Maximilian Steinbeis, Constanze Stelzenmüller, Jakob von 
Weizsäcker, and Guntram Wolff (2013), Aufbruch in die Euro-Union, in: Die Zeit, 17 October.

Bontout, Olivier and Guy Lejeune (2013), Paper on automatic stabilisers, European Commission, Directorate-General for Employment, Social Affairs and Inclusion, Brussels.

Carnot, Nicolas, Phil Evans, Serena Fatica, and Gilles Mourre (2015), Income insurance: a theoretical exercise with empirical application for the euro area, European Economy Economic Papers no. 546, European Commission, Brussels.

Caudal, Nicolas, Nathalie Georges, Vincent Grossmann-Wirth, Jean Guillaume, Thomas Lellouch, Arthur and Sode (2013), A budget for the euro area, Trésor-Economics no. 120, p. 1-12.

Dolls, Mathias, Clemens Fuest, Dirk Neumann, and Andreas Peichl (2015), An unemployment insurance scheme for the euro area? A comparison of different alternatives using micro data, Cesifo Working paper no. 5581, Center for Economic Studies and Ifo Institute, Munich.

Dolls, Mathias, Clemens Fuest, Dirk Neumann, and Andreas Peichl (2016), Reconciling insurance with market discipline: a blueprint for a European Fiscal Union, Cesifo Economic Studies, forthcoming.

Dullien, Sebastian (2013), A euro-area wide unemployment insurance as an automatic stabilizer: who benefits and who pays?, Paper prepared for the European Commission, DG EMPL, corrected version, December.

Edwards, Jeremy, and Michael Keen (1996), Tax competition and Leviathan, European Economic Review 40 (1), 113-134.

European Commission (2015), Main national accounts tax aggregates (gov_10a_taxag), compiling agency: Eurostat, http://ec.europa.eu/eurostat/en/web/products-datasets/-/GOV_10A_TAXAG (link as of 15 January 2016).

European Commission (2013), Taxation trends in the European Union, Luxembourg.

European Commission (2012), A blueprint for a genuine economic and monetary union, Brussels.

European Commission (2011), Financing the EU Budget: Report on the operation of the own resources system, Commission Staff Working Paper, Brussels.

Ferroni, Filippo, and Benjamin Klaus (2014), Euro area business cycles in turbulent times: convergence or decoupling?, European Central Bank working paper no. 1819, Frankfurt.

Ferreira-Lopes, Alexandra, and Álvaro Pina (2011), Business cycles, core, and periphery in monetary unions: comparing Europe and North America, Open Economies Review 22, pp. 565-592.

Fuest, Clemens, and Andreas Peichl (2012), European Fiscal Union: What is it? Does it work? And are there really 'no alternatives'?, IZA Policy paper no. 39, Institute for the Study of Labour, Bonn. 
Gächter, Martin, Aleksandra Riedl, and Doris Ritzberger-Grünwald (2013), Business cycle convergence or decoupling? Economic adjustment in CESEE during the crisis, BOFIT discussion paper n o. 3/2013, Bank of Finland, BOFIT Institute for Economies in Transition, Helsinki.

Giannone, Domenico, Michele Lenza, and Lucrezia Reichlin (2010), Business cycles in the euro area, in: Alberto Alesina and Francesco Giavazzi (eds.), Europe and the euro, pp. 141-167, National Bureau of Economic Research, Cambridge, MA.

Grüner, Hans-Peter (2013), The political economy of structural reform and fiscal consolidation revisited, European Economy Economic Papers no. 487, European Commission, Brussels.

Juncker, Jean-Claude, Donald Tusk, Mario Draghi, Jeroen Dijsselbloom, and Martin Schulz (2015), Completing Europe's economic and monetary union, Brussels.

Le Cacheux, Jacques (2007), Funding the EU budget with a genuine own resource: the case for a European tax, Notre Europe, policy paper.

McKay, Alisdair, and Ricardo Reis (2013), The role of automatic stabilizers in the U.S. business cycle, NBER working paper no. 19000, National Bureau for Economic Research, Cambridge, MA.

de Mooij, Ruud, and Gaëtan Nicodème (2008), Corporate tax policy and incorporation in the EU, International Tax and Public Finance 15 (4), pp. 478-498.

OECD (2014), OECD economic surveys: euro area, Paris.

Scharpf, Fritz (2009), Legitimität in europäischen Mehrebenensystemen, Leviathan 37, 244-280.

Repasi, René (2013), Legal options for an additional EMU fiscal capacity, European Parliament, Poliy Department C: Citizens' rights and constitutional affairs, Brussels.

Schratzenstaller, Margit (2004), Towards dual income taxes - a country comparative perspective, CESifo DICE report, Ifo Institute for Economic Research at the University of Munich 2 (3), pp. 23-30.

Bent Sørensena and Oved Yosha (1998), International risk sharing and European monetary unification, Journal of International Economics 45, pp. 211-238.

Spengel, Christoph Andreas Oestreicher, Christina Elschner, Timo Reister, Christof Ernst, Michael Grünewald, Katharina Finke, Jens Prassel and Lina Cui (2008), Study on the impact of reforms of corporate income taxation systems at the EU level on the size of the tax bases of the EU companies, using the model "European Tax Analyzer", Project no. TAXUD/2007/DE/325 for the EU Commission, Center for European Economic Resesarch (ZEW) and University of Göttingen, Mannheim and Göttingen.

TNS Opinion \& Social (2011), Eurobarometer 75: Europeans and the European Union budget, Spring 2011. 
van Rompuy, Herman, José Manuel Barroso, Jean-Claude Juncker, and Mario Draghi (2012), Towards a genuine economic and monetary union, Brussels.

von Hagen, Jürgen (2014), Governance of the euro area: fiscal union, debt union, fiscal freedom, Wirtschaftsdienst 94 (13), pp. 23-27.

Wolff, Guntram (2012), A budget for Europe's monetary union, Pruegel policy contribution no. 2012/22, Bruegel, Brussels. 


\section{Annex: Different tax bases for possible EMU revenue}

\begin{tabular}{|c|c|c|c|c|c|}
\hline Base & Revenue potential & $\begin{array}{l}\text { Visibility \& EU value } \\
\text { added }\end{array}$ & Implementation & Effects & Problems \\
\hline VAT & $\begin{array}{l}\text { To date, an EU-27 average } \\
\text { of below } 21 \% \text { of VAT } \\
\text { generates revenue of about } \\
7 \% \text { of GDP (European } \\
\text { Commission, 2013). Thus } \\
\text { ignoring demand elasticity, } \\
\text { another percentage point of } \\
\text { GDP could be raised by a } \\
\text { surtax } 2 \text { to } 3 \text { percentage } \\
\text { points. }\end{array}$ & -- & $\begin{array}{l}\text { - Harmonised base exists } \\
\text { - Collection mechanisms } \\
\text { exist; shifting a bigger } \\
\text { part of national VAT to } \\
\text { the EU level would be a } \\
\text { straightforward }\end{array}$ & $\begin{array}{l}\text { - Might mitigate intra-EU horizontal tax competition } \\
\text { in the context of internal devaluation } \\
\text { - Does not affect production } \\
\text { - Regressivity of indirect taxes might be problematic } \\
\text { in terms of within-country equity }\end{array}$ & $\begin{array}{l}\text { - Due to differences in national } \\
\text { tax bases and rates, a } \\
\text { percentage increase of the } \\
\text { EU part in national VAT } \\
\text { would have different impacts } \\
\text { on overall national tax } \\
\text { receipts } \\
\text { - Has no built-in property of } \\
\text { revenue side demand } \\
\text { stabilisation } \\
\end{array}$ \\
\hline $\begin{array}{l}\text { Gross national } \\
\text { income }\end{array}$ & adjustable & $\begin{array}{l}\text { - Perpetuates logic of fair } \\
\text { return } \\
\text { - To date, operating with } \\
\text { complicated correction } \\
\text { mechanisms, adding to } \\
\text { perceptions of } \\
\text { unfairness }\end{array}$ & Harmonised base exists. & $\begin{array}{l}\text { - Replicates effects of national tax systems, with } \\
\text { regard to progressivity/equity, distortions, automatic } \\
\text { stabilisation, etc. } \\
\text { - No stabilisation at the revenue side } \\
\text { - Supports EU level fiscal discipline } \\
\text { - Useful baseline of economic effects }\end{array}$ & - Logic of membership fee \\
\hline $\begin{array}{l}\text { Eco-taxation, } \\
\text { e.g. fossil } \\
\text { fuels }\end{array}$ & $\begin{array}{l}\text { Assessed to be substantial } \\
\text { (Begg, 2011). }\end{array}$ & & $\begin{array}{l}\text { Low administration cost at } \\
\text { EU level. }\end{array}$ & $\begin{array}{l}\text { - Mitigate negative externalities of environmental } \\
\text { damage } \\
\text { - Might challenge equity within countries; need to } \\
\text { compensate }\end{array}$ & $\begin{array}{l}\text { - Contradictory objectives of } \\
\text { revenue vs. disincentives to } \\
\text { ecological externalities } \\
\text { - Would distribute the } \\
\text { generation of revenue } \\
\text { unevenly across Member } \\
\text { States, giving an advantage } \\
\text { to nuclear energy, and likely } \\
\text { to meet resistance of } \\
\text { catching-up latest EU } \\
\text { entrants } \\
\text { - For the ETS scheme, revenue } \\
\text { is earmarked for national } \\
\text { climate action }\end{array}$ \\
\hline $\begin{array}{l}\text { Financial } \\
\text { activity tax } \\
\text { (FAT)/financi } \\
\text { al transaction } \\
\text { tax (FTT) }\end{array}$ & $\begin{array}{l}\text { See Impact Assessment } \\
2011\end{array}$ & $\begin{array}{l}\text { - Assigns revenue } \\
\text { generation (ignoring } \\
\text { incidence) to sector } \\
\text { supposed to benefit most } \\
\text { from the common } \\
\text { currency } \\
\text { Might correct the bias in } \\
\text { favour of financial } \\
\text { services from VAT } \\
\text { exemption }\end{array}$ & & & $\begin{array}{l}\text { - Most revenue could be } \\
\text { technically generated in UK } \\
\text { if based on place of } \\
\text { transaction; difficult to tie to } \\
\text { EMU expenditure }\end{array}$ \\
\hline
\end{tabular}




\begin{tabular}{|c|c|c|c|c|c|}
\hline $\begin{array}{l}\text { Corporate } \\
\text { income tax }\end{array}$ & $\begin{array}{l}\text { To date, an average } \\
\text { (implicit) tax rate on } \\
\text { corporate income of } 20.8 \% \\
\text { raises revenue of } 2.4 \% \text { of } \\
\text { GDP in the euro area } \\
\text { (European Commission, } \\
\text { 2013). Thus about } 1 \text { per } \\
\text { cent of GDP is raised with } \\
\text { about } 8.7 \text { percentage } \\
\text { points. Corporate taxation } \\
\text { at EMU levels would allow } \\
\text { for efficiency-improving } \\
\text { higher rates as well as a } \\
\text { broader base, thus Member } \\
\text { States would not have to } \\
\text { forego } 40 \% \text { of their CIT } \\
\text { revenue. }\end{array}$ & $\begin{array}{l}\text { - Assigns revenue } \\
\text { generation (ignoring } \\
\text { incidence) to sector } \\
\text { supposed to gain most } \\
\text { from internal market and } \\
\text { the more international } \\
\text { players in that sector in } \\
\text { particular. } \\
\text { - Impossibility of } \\
\text { assignment of revenue } \\
\text { from MNEs favourably } \\
\text { counters the logic of } \\
\text { national contributions } \\
\text { and fair return } \\
\text { - Might generate } \\
\text { additional revenue, to } \\
\text { the extent that MNEs } \\
\text { contribute under- } \\
\text { proportionally to } \\
\text { national budgets }\end{array}$ & $\begin{array}{l}\text { Proposal for common base } \\
\text { exists. }\end{array}$ & $\begin{array}{l}\text { - Compatible with enhancing efficiency and } \\
\text { eliminating distortions (high compliance costs for } \\
\text { internationally active enterprises) in internal market } \\
\text { - Would mitigate horizontal tax competition across } \\
\text { EMU Members } \\
\text { - Particularly suited for euro area revenue, given } \\
\text { higher levels of integration and mobility in EMU } \\
\text { - Fostering a level playing field between (national) } \\
\text { SME and (international) MNE adds to vertical equity } \\
\text { - Advantage of revenue side stabilisation effect } \\
\text { - EU level design of the tax base would allow better } \\
\text { alignment with EU industrial policy objectives } \\
\text { - Ignoring incidence, a tax burden on the corporate } \\
\text { sector would add to horizontal equity within EU } \\
\text { Members to the extent that the concentration of } \\
\text { business wealth is higher than that of income } \\
\text { - Would transform the CIT to a shared revenue base, } \\
\text { inducing vertical tax competition }\end{array}$ & $\begin{array}{l}\text { - To date, there is little } \\
\text { willingness of Member States } \\
\text { to introduce a common } \\
\text { corporate tax base, even as a } \\
\text { voluntary possibility for } \\
\text { enterprises } \\
\text { - It might be interesting to } \\
\text { consider CIT as a source of } \\
\text { revenue for EMU, as here } \\
\text { Members expect tangible } \\
\text { benefits from a common } \\
\text { fund: the case for pro- } \\
\text { European solutions could be } \\
\text { more forcefully made }\end{array}$ \\
\hline $\begin{array}{l}\text { Personal } \\
\text { income tax }\end{array}$ & $\begin{array}{l}\text { To date, implicit tax rates } \\
\text { on capital of } 28.9 \% \text { in the } \\
\text { EA-17 raise revenue of } \\
7.9 \% \text { of GDP. } \\
\text { Thus revenue of } 1 \% \text { of } \\
\text { GDP corresponds to a rate } \\
\text { of } 3.7 \text { percentage points. } \\
\text { However, the personal } \\
\text { income tax base from } \\
\text { financial assets is more } \\
\text { narrow than capital more } \\
\text { broadly. }\end{array}$ & & $\begin{array}{l}\text { - Differences in the } \\
\text { definition of the base } \\
\text { violate horizontal equity } \\
\text { across Members. } \\
\text { - Implementation of a } \\
\text { common base appears } \\
\text { insurmountable } \\
\text { - PIT on financial assets } \\
\text { (Le Cacheux, 2007) } \\
\text { could be an interesting } \\
\text { to consider; } \\
\text { administration would be } \\
\text { facilitated by } \\
\text { information exchange } \\
\text { under the Savings } \\
\text { Directive } \\
\end{array}$ & $\begin{array}{l}\text { - PIT on financial assets would add to EU-wide } \\
\text { vertical equity, as financial assets are highly } \\
\text { concentrated in EU populations }\end{array}$ & \\
\hline $\begin{array}{l}\text { Social security } \\
\text { contributions } \\
\text { (SSCI) }\end{array}$ & $\begin{array}{l}\text { Compensation of } 50 \% \text { of } \\
\text { earnings shortfalls for } \\
\text { unemployment up to one } \\
\text { year could be financed } \\
\text { with payroll contributions } \\
\text { of } 1.7 \% \text {, generating } \\
\text { revenue of } 0.7 \% \text { of euro } \\
\text { area GDP }\end{array}$ & $\begin{array}{l}\text { SSC-financed common } \\
\text { EMU unemployment } \\
\text { insurance would visibility } \\
\text { and EU value added most } \\
\text { and could fill a void in EU } \\
\text { policies with negative } \\
\text { impacts on legitimacy } \\
\text { perceptions at present }\end{array}$ & $\begin{array}{l}\text { Establishing EMU } \\
\text { unemployment } \\
\text { insurance provision is } \\
\text { full of complex } \\
\text { technical challenges }\end{array}$ & $\begin{array}{l}\text { - Creating a EMU-wide common unemployment } \\
\text { insurance fund would necessitate commensurate } \\
\text { reductions in national schemes' contributions and } \\
\text { coverage. } \\
\text { - On stabilisation power and geographic distribution of } \\
\text { benefits, see Bontout and Lejeune (2013). }\end{array}$ & \\
\hline
\end{tabular}

